\title{
INVENTARISASI KHAZANAH KULINER TRADISIONAL DESA PAKUWON KECAMATAN CISURUPAN KABUPATEN GARUT DALAM KONTEKS PEMBANGUNAN KAMPUNG WISATA HALAL
}

\author{
Riadi Darwis \\ Sekolah Tinggi Pariwisata Bandung \\ riadidarwis@gmail.com
}

\begin{abstract}
ABSTRAK
Program pariwisata halal di Indonesia sedang giat dilaksanakan di sejumlah daerah termasuk di dalamnya Provinsi Jawa Barat. Salah satu di antaranya adalah kawasan Kabupaten Garut tepatnya di Desa Pakuwon, Kecamatan Cisurupan. Metode penelitian yang penulis gunakan adalah metode kualitatif. Sampel kulinernya adalah yang ada di Kawasan Kampung Sindang Daweung dan sekitarnya. Teknik pengumpulan data yang dipakai meliputi: observasi, wawancara, dan studi dokumentasi. Teknis analisis yang dipakai adalah analisis statistik deskriptif. Temuan penelitian menunjukkan bahwa: (1) jumlah ragam kuliner yang ada mencapai 189 jenis; (2) teknik kuliner yang dilakukan mencapai 55 dari 69 teknik kuliner Sunda; (3) konteks pembuatan dan penyajian kuliner terbagi atas rutinitas kebutuhan domestik keluarga, komersial, dan acara seremonial adat, keagamaan maupun hari-hari besar nasional; (4) kehalalan bahan makanan hampir mendekati $100 \%$ halal, perolehan $100 \%$ halal, proses hampir mendekati 100\%, aspek higiene dan sanitasi masih kurang.
\end{abstract}

Kata kunci: ragam kuliner, teknik pengolahan kuliner, konteks pembuatan dan penyajian kuliner, kehalalan kuliner.

\section{THE INVENTORY OF KHAZANAH CULINARY TRADITIONAL AT PAKUWON VILLAGE DISTRICT REGENCY OF GARUT IN CONTEXT OF DEVELOPMENT OF HALAL TOURISM}

\begin{abstract}
Halal tourism program in Indonesia is implemented in a number of areas including West Java Province. One of them is the Garut district, in the village Pakuwon, District Cisurupan. The research method that I use is a qualitative method. Sample culinary is in Kampung Sindang Daweung and surrounding areas. The data collection techniques used include: observation, interviews, and documentation. Technical analysis is used is descriptive statistical analysis. The
\end{abstract}


findings show that: (1) the number of culinary variety reaches 189 kinds; (2) The culinary techniques that do reach 55 of 69 Sunda culinary techniques; (3) the context of creation and presentation of culinary divided into routine domestic needs of the family, commercial, and customary ceremonial, religious and national big days; (4) halal groceries are close to $100 \%$ kosher, halal acquisition of $100 \%$, the process is almost close to $100 \%$, the aspect of hygiene and sanitation are lacking.

Keywords: culinary variety, culinary processing technique, the context of the creation and presentation of culinary, halal culinary

\section{PENDAHULUAN}

Pembangunan sektor kepariwisataan di Indonesia secara nyata telah memberikan bukti berupa devisa yang sangat besar. Menteri Pariwisata Republik Indonesia, Arief Yahya menjelaskan bahwa sektor pariwisata pada 2019 diharuskan dapat berkontribusi pada PDB nasional sebesar 8\% dengan besaran devisa Rp240 triliun, penciptaan lapangan kerja untuk 13 juta orang, dan kunjungan wisatawan mancanegara sebanyak 20 juta wisman; pada 2015 diproyeksikan mencapai 4\% dengan devisa Rp 155 triliun, penciptaan lapangaan kerja 11,3 juta orang; pada 2016 diproyeksikan mampu berkontribusi 5\% dengan devisa Rp 172 triliun, penciptaan lapangan kerja 11,7 juta orang, serta kunjungan wisatawan mancanegara sebanyak 12 juta orang (Venue Magz, 2015: Tersedia: http://www.venuemagz.com/ artikel/news/2015/10/tahun-2016-pariwisatamenyumbang-devisa-rp172-triliun/ [1 November 2016]). Hal ini menandakan bahwa optimisme pembangunan di sektor pariwisata begitu besar.

Seiring dengan dinamika dunia kepariwisataan dunia, saat ini tren pariwisata halal tengah marak bahkan menjadi perbincangan dan program yang diseriusi di sejumlah negara. Tren ini tersuluti oleh kesadaran masyarakat dunia terhadap produk halal yang terus meningkat. Tingkat pemahamannya tidak di persoalan makanan dan minuman saja namun menyangkut wisata halal, busana, kosmetik, dan lainnya yang sudah menjadi kebutuhan.

Berikut adalah sejumlah negara nonmuslim seperti Thailand, Jepang, Korea dan Australia yang tanpa ragu mengembangkan halal tourism sebagai brand. Di antara negara tersebut ada yang memiliki buku panduan wisata untuk muslim karena sebagai tambahan layanan bagi wisatawan Muslim. Thailand sebagai negara yang penduduk muslimnya $5 \%$ berani menyatakan sebagai tujuan wisata dan life style halal.

Sebagai pembanding, data berikut bisa menjadi bahan kajian untuk proyeksi ke depan mengingat Indonesia sebagai negara berpenduduk sekitar 250 juta dan mayoritas adalah muslim. Menurut catatan International Trade Center 2015, pasar muslim untuk makanan pada 2014 sebesar 1,128 miliar dolar. Keuangan 1,814 miliar dolar, travel 142 miliar dolar, kosmetika 142 miliar dolar, fashion 230 miliar dolar, media rekreasi 179 miliar dolar, farmasi 75 dolar. Itu belum termasuk sektor pendidikan, obat-obatan, dan seni budaya. 
Saat ini, Indonesia masih tertinggal jauh dengan negara tetangga Malaysia yang sudah puluhan tahun lalu menerapkan jaminan halal. Meski begitu, lambat laun perkembangan halal di Indonesia terus meningkat. Di sektor wisata halal, Indonesia berhasil merebut tiga gelar dalam World's Best Halal di Abu Dabhi, Uni Emirat Arab, Oktober 2015 lalu Sapta Nirwandar dalam Suqi Radio, 2016: Tersedia:http://suqiradio.com/2016/05/03/halal-market-jadi-trend-di- $\quad$ sejumlahnegara-di-dunia/ [1 November 2016].

Sejalan dengan arah kebijakan pemerintah, program pariwisata halal di Indonesia sedang giat dilaksanakan di sejumlah daerah termasuk di dalamnya Provinsi Jawa Barat. Sejumlah kawasan di Jawa Barat sangat terkenal dengan berbagai potensi wisata yang menarik untuk dikembangkan. Salah satu di antaranya adalah kawasan Kabupaten Garut.

Ketertarikan wilayah Kabupaten Garut dalam aspak potensi wisata tidak perlu diragukan terutama untuk potensi alam dan budayanya. Saat ini STP Bandung sebagai kepanjangan tangan dari Kementerian Pariwisata Republik Indonesia sedang melakukan sejumlah kegiatan yang mengusung pembentukan destinasi wisata di sejumlah kawasan di Indonesia. Satu di antaranya yang terdapat di Kabupaten Garut tepatnya di Desa Pakuwon, Kecamatan Cisurupan. Berdasarkan kajian sebelumnya pemilihan kawasan tersebut termasuk tepat untuk dikembangkan sebagai proyek percontohan pendirian kampung/ desa wisata halal dalam rangka pemandirian desa.

Kajian wisata halal/ syariah ini berbeda dengan penelitian terdahulu (Andriani, 2015) yang lebih mengedepanan data tarik, amenitas, aksesibitas, dan market wisatawan secara makro. Pada penelitian ini penulis lebih mengkhususkan pada aspek kehalalan di bidang kuliner yang mencakup inventarisasi ragam kuliner, teknik pengolaahannya, konteks pembuatan/ penyajian, dan kadar kehalalannya.

\section{A. Profil Desa Pakuwon}

Desa Pakuwon adalah desa hasil pemekaran dari Desa Pangauban dan Desa Simpangsari. Pemakaran ini terjadi sekitar tahun 1987 dengan luas wilayah 152 ha. Desa ini merupakan salah satu desa yang terletak di Kecamatan Cisurupan Kabupaten Garut. Pada saat ini Desa Pakuwon membagi wilayah teritorialnya ke dalam 2 dusun, 6 rukun warga (RW) dan 31 rukun tetangga (RT). Pembagian wilayah dusun tersebut didasarkan pada kondisi geografis wilayah yang berdekatan.

Berdasarkan administrasi kewilayahan, Desa Pakuwon memiliki batas dengan desa lainnya sebagai berikut. Batas sebelah Utara adalah Desa Simpangsari. Batas sebelah Selatan adalah Desa Sirnagalih. Batas sebelah Timur adalah Desa Mulyasari, Bayongbong. Batas sebelah Barat adalah Desa Pangauban.

Berdasarkan unsur demografi, Desa Pakuwon pada saat ini berjumlah 4.635 jiwa. Penduduk berjenis kelamin laki-laki sebanyak 2.347 jiwa dan perempuan sebanyak 2.288 jiwa dengan jumlah kepala keluarga sebanyak 1.094 kepala keluarga. Mereka secara mayoritas termasuk etnis Sunda yang relatif masih kental. Penduduk miskin Desa Pakuwon pada saat ini tercatat sebanyak 1.844 
orang keluarga miskin. Menurut data PPLS 2011(BPS) jumlah penduduk miskin di desa tersebut sebanyak 497 Keluarga (45\%).

Berdasarkan tingkat pendidikan penduduknya, Desa Pakuwon ini relatif masih rendah. Hal ini terlihat dari komposisi lulusan secara mayoritas berpendidikan sekolah dasar (SD) dan sebagian besar lainnya tidak sekolah dan tidak tamat SD.

Desa Pakuwon merupakan desa yang cocok untuk pengembangan usaha pertanian. Hal ini ditunjukkan oleh beberapa komoditas tanaman pertanian yang dibudidayakan memiliki hasil yang memuaskan dan berdampak pada peningkatan kesejahteraan masyarakat. Salah satu contoh komoditas tanaman pertanian tersebut adalah padi. Budidaya padi sejak dulu hingga saat ini merupakan komoditas yang selalu dikembangkan oleh masyarakat Desa Pakuwon.

Dilihat dari topografi, kawasan Desa Pakuwon merupakan tanah pegunungan yang berbukit-bukit dengan kondisi tanah berhumus yang cukup subur. Karenanya seperti desa-desa lain di Kecamatan Cisurupan, desa ini merupakan sentra produksi komoditas sayur mayur. Lahan kawasan tersebut sebagian besar digunakan untuk lahan pertanian sawah (120 ha) dan perladangan (17,5 ha), perkebunan (23 ha) sedangkan sisanya merupakan tanah pemukiman (15 ha), fasilitas umum, makam, dsb. Berikut ini penulis sampaikan beberapa komoditas yang dibudidayakan di Desa Pakuwon di antaranya:

Pada aspek historis peradaban masa lalu, Desa Pakuwon yang terletak di kawasan Gunung Papandayan memiliki catatan tersendiri . Berdasarkan data literasi dunia filologi, kawasan desa ini masuk pada area bersejarah yang ada hubungannya dengan peradaban di masa kerajaan Pajajaran. Kawasan ini dianggap begitu penting dalam naskah Sunda kuna Bujangga Manik: Jejak Langkah Peziarah. Naskah ini ditulis dalam bahasa Sunda Kuna pada 1627 Masehi (atau 1629) dan tersimpan di koleksi Bodleian di Oxford (Noorduyn dan Teeuw, 2009: 17). Naskah ini terdiri atas 29 helai daun lontar, masing-masing berisi hampir 56 baris yang terdiri atas 8 suku kata (Noorduyn dan Teeuw, 2009: 19) .

Inti cerita naskah tersebut dipaparkan Noorduyn (dalam Noorduyn dan Teeuw, 2009: 17) bahwa:

"pahlawan dalam ceita ini adalah petapa Sunda-Hindu yang, meskipun berkedudukan sebagai pangeran (tohaan) di istana Pakuan (yang terletak di dekat Bogor, Jawa Barat, dewasa ini), lebih suka hidup sebagai rohaniwan" (Noorduyn 1982: 413). Dengan niat seperti itu dia mengadakan dua kali perjalanan dari Pakuan ke Jawa Tengah dan Timur, termasuk ke Bali dalam perjalanan pertama, lalu kembali lagi. Sepulang mengembara dia bertapa di sebuah pegunungan di Jawa Barat, tempat keberadaan jasmaniahnya berakhir; pada bagian akhir teks tersebut perjalanan rohaninya ke kahyangan digambarkan secara sangat terperinci.

Pada naskah tersebut secara gamblang dijelaskan mengenai sudut pandang sang pangeran pengelana tersebut (Bujangga Manik) mengenai keindahan panorama alam yang dilihat dari Gunung Papandayan (Noorduyn, 2009: 18). 
Gambaran ini bisa dilihat dalam baris naskah 1165-1275 (Noordyn dan Teeuw, 2009: 306-309)

\section{B. Konsep Desa Wisata dan Payung Hukumnya}

Desa wisata adalah suatu bentuk integrasi antara atraksi, akomodasi dan fasilitas pendukung yang disajikan dalam suatu struktur kehidupan masyarakat yang menyatu dengan tata cara dan tradisi yang berlaku.Desa wisata sebagai salah satu program pembangunan skala nasional di bidang kepariwisataan secara hukum ternaungi oleh peraturan menteri. Peraturan yang dimaksud adalah adalah Peraturan Menteri Kebudayaan Dan Pariwisata Nomor: PM.26/UM.001/ MKP/2010 tentang Pedoman Umum Program Nasional Pemberdayaan Masyarakat (PNPM) Mandiri Pariwisata melalui Desa Wisata. Dalam peraturan tersebut dijelaskan bahwa desa wisata merupakan bentuk upaya percepatan penanggulangan kemiskinan dan perluasan kesempatan kerja dengan melibatkan masyarakat secara lebih luas (Menteri Kebudayaan dan Pariwisata RI, 2010: hlm. $1)$.

Pada lampiran peraturan tersebut, terdapat Pedoman Program Nasional Pemberdayaan Masyarakat melalui desa wisata. Pedoman yang dimaksud memuat konsep, strategi, tahapan progam dan pelaksanaan PNPM Mandiri Pariwisata, dalam rangka membangun kesadaraan masyarakat dan penguatan kelembagaan, sehingga masyarakat dapat menjadi pelaku pariwisata.

Konsekuensinya, penanggulangan kemiskinan melalui sektor pariwisata memerlukan suatu strategi, instrumen dan program-program aksi yang tepat sesuai karakteristik permasalahan yang ada.

Harapannya dengan adanya desa wisata pada akhirnya akan memberdayakan masyarakat sekitarnya. Pemberdayaan masyarakat adalah menciptakan/ meningkatkan kapasitas masyarakat baik secara individu maupun berkelompok dalam memecahkan berbagai persoalan terkait upaya peningkatan kualitas hidup, kemandirian, dan kesejahteraannya.

Untuk mencapainya perlu dilakukan suatu kajian dengan mengidentifikasi dan menginventarisasi berbagai hal terkait atraksi, akomodasi dan fasilitas pendukung yang disajikan dalam suatu struktur kehidupan masyarakat yang menyatu dengan tata cara dan tradisi yang berlaku. Salah satu yang menjadi ketertarikan penulis adalah bidang kuliner tradisional yang ada di lingkungan masyarakat desa tersebut untuk melengkapi dan memperkuat daya saing dan kekhasan potensi wisata yang ada di sekitar desa tersebut.

\section{Unsur Kebudayaan}

Kebudayaan yang secara etimologi berasal dari bahasa Sansekerta "budhayah" yang merupakan bentuk jamak dari "budhi" yang berarti 'budi' atau 'akal'. Dengan demikian makna kebudayaan adalah hasil budi atau akal manusia untuk mencapai kesempurnaan hidup (Ahmadi, 2003: 50).

Berdasarkan sejumlah pandangan bahwa kebudayaan memiliki pengertian

yang berbeda-beda. Koentjaraningrat (dalam Ahmadi, 2003: hlm. 54) merumuskan bahwa sedikitnya ada tiga wujud kebudayaan yang meliputi: (1) wujud ide, gagasan, nilai-nilai, norma, peraturan; (2) wujud kelakuan 
berpola dari manusia dalam masyarakat dan (3) wujud benda-benda hasil karya manusia.

Wujud kebudayaan yang pertama adalah wujud ide yang bersifat abstrak dan tidak dapat diraba. Saat ini wujud ide ini akan tampak bila dibuat dalam karya tulis baik itu melalui tape, arsip, koleksi microfilm, komputer, dll.

Wujud kebudayaan yang kedua adalah kelakuan berpola dari manusia dalam masyarakat seperti berinteraksi dengan anggota masyarakat lainnya. Kegiatan tersebut lazim berpola menurut aturan-aturan tertentu berdasarkan adat istiadat.

Wujud kebudayaan yang ketiga adalah hasil karya manusia. Wujud ini bersifat konkret, dapat diraba, dilihat, dirasa, dan difoto (didomunteasi).

Selanjutnya, Koentjaraningrat dalam Ahmadi (2003: hlm. 55) merumuskan unsur kebudayaan atas tujuh anasir berikut ini: (1) sistem religi dan upacara keagamaan, (2) sistem dan organisasi kemasyarakatan, (3) sistem pengetahuan, (4) bahasa, (5) kesenian, (6) sistem mata pencaharian hidup, dan (7) sistem teknologi dan peralatan.

Menurutnya, wujud kebudayaan tersebut mempunyai kegunaan yang sangat besar bagi manusia dan masyarakat luas dalam menghadapi berbagai kekuatan yang harus dihadapinya seperti kekuatan alam. Kebudayaan dapat digunakan untuk melindungi manusia dari ancaman dan bencana alam. Kebudayaan pun dapat dipergunakan untuk mengatur hubungan sekaligus wadah segenap manusia sebagai anggota masyarakat. Tanpa kebudayaan, manusia tidak bisa membentuk peradaban seperti sekarang.

Salah satu varian dari anasir kebudayaan yaitu kesenian dan subkeseniannya yang dimaksud adalah seni kuliner. Seni kuliner adalah sebuah konsep seni perpaduan pengolahan makanan dan minuman yang tumbuh dalam masyarakat. Seni kuliner merupakan wujud kebudayaan hasil karya manusia yang bersifat materi dan konkret dalam upaya membuat aneka makanan maupun minuman sebagai bagian kebutuhan primer manusia.

\section{Kebudayaan Sunda}

Berikut ini penulis petik sebuah pernyataan tentang makna kebudayaan Sunda yang disampaikan Ekadjati (2014: hlm 4)

Kebudayaan Sunda yaitu kebudayaan yang hidup, tumbuh dan berkembang di kalangan orang Sunda yang pada umumnya berdomisili di tanah Sunda. Kebudayaan Sunda dalam tata kehidupan sosial budaya bangsa Indonesia digolongkan ke dalam kebudayaan daerah (Lihat: Undang-Undang Dasar 1945, terutama penjelasan pasal 32 dan pasal 36) dan ada yang menamai kebudayaan suku bangsa, untuk membedakan kebudayaan daerah lain di Indonesia, kebudayaan Sunda memiliki ciri-ciri khas tersendiri yang membedakannya dari kebudayaan lainnya.

Bemmelen dalam Ekadjati (2014: hlm 1-2) mengatakan bahwa Sunda adalah istilah yang digunakan untuk menamai dataran bagian barat laut wilayah India Timur, sedangkan dataran bagian tenggara dinamai Sahul. Dataran Sunda dikelilingi oleh sistem Gunung Sunda yang melingkar sepanjang $7.000 \mathrm{~km}$. 
Dataran Sunda terdiri atas dua bagian utama yaitu bagian utara meliputi Kepluaan Filipina dan pulau-pulau karang sepanjang lautan Pasifik bagian barat serta bagian selatan yang terbentang dari timur ke barat mulai dari Maluku bagian selatan hingga lembah Brahmaputra di Assam (India). Bagian selatan dataran Sunda dibentuk oleh kawasan mulai Pulai Banda di timur terus menuju barat melalui pulau-pulau di Kepulauan Sunda Kecil (the Lesser Sunda Islands), Jawa Sumatera, Kepulauan Andaman, dan Nikobar sampai ke Arakan Yoma di Birma. Selanjutnya dataran ini bersambung dengan kawasan Sistem Gunung Himalaya di barat dan dataran Sahul di timur.

Istilah "Sunda"berasal dari kata sund (Inggris: sun 'matahari') yang bermakna bercahaya dan terang benderang (Suryalaga dalam Sudaryat, 2014:1). Istilah Sunda tersebut tercatat dalam prasasti Cibadak, Kabupaten Sukabumi. Dalam prasasti yang berangka tahun 952 saka (1030 masehi) tersebut tertoreh nama seorang raja bernama Sri Jayabupati yang menyebut dirinya sebagai Raja Sunda atau Raja Kerajaan Sunda (Ekadjati dalam Sudaryat, 2015: hlm. 1). Kerajaan Sunda didirikan Maharaja Tarusbawa (591-645 saka) atau 669-723 Masehi.

Dalam penjelasan lainnya, penulis menemukan ada peristilahan "kesundaan". Menurut Ekadjati dalam Sudaryat (2015: hlm. 3) kesundaan atau kasundaan atau sundanologi adalah pengetahuan dan penjiwaan penghidupan (hirup-hurip) orang Sunda baik secara individual maupun secara sosial sepanjang perjalanan hidup mereka. Dengan kata lain, kasundaan adalah pengetahuan dan penjiwaan tentang kehidupan masyarakat Sunda dan kebudayaannya.

Tidak sedikit berbagai artefak kebudayaan yang tersirat dan tersurat tentang dalamnya unsur spiritualitas masyarakat Sunda pada beberapa naskah kuna. Salah satu di antaranya adalah naskah Sanghyang Siksakandang Karesian, naskah Carita Parahiyangan, naskah Amanat Galunggung, naskah Fragmen Carita Parahiyangan, dan naskah Sanghyang Raga Dewata. Khusus naskah Sanghyang Sikasakandang Karesian dianggap oleh para ahli sebagai ensiklopedianya kultur masyarakat Sunda. Naskah tersebut diduga ditulis oleh seorang cendekia tanpa identitas pada tahun 1140 Saka/ 1518 Masehi atau abad ke-16 Masehi. Dugaan kuat naskah tersebut ditulis pada masa Sri Baduga Maharaja yang memerintah di Pakuan Papajaran tahun 1482-1521 Masehi (Suryani N.S., 2011: hlm. 131).

\section{E. Ragam Teknik Kuliner Tradisional Sunda}

Selain peristilahan yang telah disebutkan di atas, pada naskah Siksa Kadang Karesian yang ditulis pada 1518 Masehi hasil terjemahan Atja dan Saleh Danasasmita pada kropak 630 seri MSB (Manuscript Soenda B), penulis menemukan adanya istilah "hareup catra". Istilah ini merujuk pada nama profesi di bidang pengolahan makanan. Penulis menyimpulkan bahwa masyarakat Sunda kuna telah menempatkan profesi ahli memasak menjadi bagian penting dalam kehidupan masyarakatnya jauh sebelum naskah tersebut dibuat. 
Dalam salah satu bagian naskahnya secara gamblang pada lembar XVII tertulis sejumlah nama teknik mengolah maupun jenis nama masakan sebagai berikut.

Sa[wa]lwir[a] ning oolahan ma: nyupar nyapir, rara ma(n)di, nyocobek, nyopong koneng, nyanglakeun, nyarengseng, nyeuseungit, nyayang ku pedes, beubeuleuman, papanggangan, kakasian, hahanyangan, dirurum, diamis-amis, sing sawatek kaolahan, hareup catra tanya.

(Segala macam masakan: nyupar nyapir, rara mandi, nyocobek, nyopong koneng, nyanglakeun, nyarengseng, kakasian, hahayangan, rarameusan, diruruum, diamis-amis; segala macam masakan, tanyalah hareup catra (ahli masak). (Darwis, 1995: hlm. 5-6)

Teknik kuliner pada masyarakat Sunda cukup bervariasi. Teknik tersebut ada hubungannya dengan menggunakan beberapa media seperti halnya air yang jumlahnya sedikit dan banyak, minyak dengan jumlah yang sedikit ataupun banyak, api baik langsung atau tidak langsung, asap sinar matahari, ragi dan sebagainya. Dalam tahap pengolahaan untuk jenis makanan tertentu tidak cukup hanya dengan sekali perlakuan. Hal ini dimaksudkan karena bahannya terlalu keras, agar bumbu meresap, menciptakan aroma baru/ cita rasa baru dan sebagainya.

Tujuan utama pengolahan makanan berdasarkan semua jenis teknik yaang dimaksud secara umum bertujuan agar: (1) menjadikan makanan empuk dan melembutkan bagian dalam makanan tersebut; (2) menjadikan makanan lebih bercita rasa; (3) menjadikan makanan dapat dicerna; (4) mensterilkan makanan dari bakteri merugikan yang dapat menimbulkan keracunan; (5) menghasilkan kualitas makanan dari segi warna, cita rasa, dan tekstur; serta (6) meminimalkan kehilangan kadar gizi makanan. (Stevenson, 1991: )

Berdasarkan hasil kajian Darwis (1995b: 1-8) jumlah teknik kuliner yang tumbuh dan berkembang di masyarakat Sunda mencapai 40 teknik. Keempat puluh teknik tersebut meliputi: asinan (T1), bakar/ beuleum (T2), bubur (T3), bibis (T4), bubuy/ mubuy/ mubus(T5), ceos/ gejos (T6), cobek (T7), empos (T8), eumping (T9), ganggang (T10), garang (T11), geprek/ geprak (T12), gigih (T13), goreng ((T14), jemur/ poe (T15), karih (T16), kere/ deeng/ dendeng (T17), leumpeuh (T18), leumeung (T19), liwet (T20), manisan (T21), pais (T22), peuyeum (T23), pindang (T24), rarameusan (T25), rebus/ godog (T26, rendos (T27), rendam/ keueum (T28), rerab (T29), ruum/ diruruum/diseuseungit/ diwangikan (T30), sangrai (T31), semur (T32), seupan/ kukus (T33), tumbuk/ tutu (T34), tumis (T35), tutug (T36), tuum (T37), tuus/ tiris (T38), unun (T39, dan ungkeb (T40).

\section{F. Konteks Pembuatan dan Penyajian Kuliner Tradisional Sunda}

Pembuatan dan penyajian kuliner dalam tradisi masyarakat Sunda secara umum dapat dibedakan menjadi tiga: pembuatan dan penyajian kuliner untuk kebutuhan sehari-hari, usaha, dan hajatan upacara adat. Upacara adat itu sendiri dapat diklasifikasi pada beberapa hal yang berhubungan dengan: (1) mata 
pencaharian seperti bertani, (2) pernikahan, (3) kehamilan, (4) kelahiran), (5) kematian, (6) keselamatan dan musibah, dan (7) hari-hari besar keagamaan (Muludan, Muharaman, Rajaban, puasa Ramadan, Idul Fitri, dan Idul Adha) maupun nasional.

Berikut ini beberapa adat maupun upacara ritual keagamaan alainnya yang tumbuh dan hidup dalam masyarakat Sunda. Berikut adalah beberapa adat yang ada hubungannya dengan kegiatan pernikahan, kehamilan, kelahiran, kematian, serta keselamatan dan musibah: (1) adat mulasara bali, (2) adat ngaraksa nu ngajuru, (3) adat tingkeban, (4) adat nu nyiram, (5) adat ngariksa nu reuneuh, (6) adat ngajuru, (7) adat puput puseur, (8) adat ngawinkeun, (9) seserahan, (10) adat ngurus orok, (11) adat d sunatan, (12) adat ngalamar, (13) salametan, (14) mere ngaran, (15) ngalayad nu gering, (16) nyambungan, dan (17) akekah.

Untuk kegiatan di bidang pertanian ada sejumlah adat yang dijalankan oleh masyarakat Sunda. Salah satu di antaranya adalah: (1) balabuh, upacara pengukuran sawah-sawah yang akan ditanami padi; (2) mapag sari, menyongsong kehadiran Dewi Sri dari sawah yang akan disimpan dan dimasukkan ke dalam lumbung (leuit); (3) mitembeyan, upacara permulaan pelaksanaan kegiatan (misalnya, mitembeyan tandur (menanam padi), metembeyan macul (mulai mencangkul di sawah)); (4) netepkeun, upaca penyimpanan padi di leuit; (5) ngalaksa, upacara untuk memulai pemanfaatan padi yang baru dipanen dengan cara membuat laksa (makanan sejenis mie yang dibuat dari tepung beras); (6) ngalesu, upaca menumbuk padi di daerah Garut, di Bandung upacara ini disebut ngaleunggeuh, di Banten disebut ngarempug nutu, sebutan-sebutan lainnya untuk menyebut upacara ini adalah ngabendrong, ngagondang, dan ngagender; (7) ngalungsurkeun, ada dua macam istilah dalam upacara ngalungsurkeun: (a) pertama, upacara untuk menaburkan biji padi (tebar), (b) dua, upacara menurunkan padi dari leuit yang akan ditumbuk untuk dijadikan beras; (8) nyalin, upacara untuk menuai padi; dan (9) parawanten $=$ sesajen dalam upacara penghormatan kepada Dewi Sri yang berupa makanan (buah-buahan berupa: mangga, salak manggis, dukuh, pisitan, kokosan, bencoy, pisang raja, pisang mas, pisang raja cere, dan sebagainya; ubi-ubian berupa: ubi, ketela pohon, ganyol, sagu, talas, dan sebagainya; panganan dari beras: kupat leupeut, tangtang angin, puncak manik, tumpeng, bubur bodas dan bubur beureum; panganan dari beras ketan misalnya: opak, rangginang, peuyeum ketan, hideung, raragudig, gegeplak, mayang mekar, kolontong, wajit, dodol, dan sebagainya; rurujakan misalnya: rujak roti, rujak kelapa, rujak pisang, rujak jeruk, rujak asem, rujak konyal, dsb.).

Selain adat-adat yang disebutkan di atas ada pula beberapa upara hari-hari besar keagamaan maupun nasional yang dijalankan masyarakat Sunda sperti (1) Muludan, (2) Muharaman, (3) Rajaban, (4) puasa Ramadan, (5) Idul Fitri, dan (6) Idul Adha.

\section{G. Kehalalan Kuliner}

Tren gaya hidup manusia modern saat ini sudah mulai meningkat terutama pada upaya memperoleh makanan sehat dan berkualitas. Hal ini berhubungan dengan upaya pemeliharaan dan peningkatan derajat kesehatan, kebugaran, dan 
kualitas hidup manusia mengingat telah banyak korban akibat gaya hidup yang salah di sebagian masyarakat dalam mengonsumsi makanan. Salah satu contohnya adalah: darah tinggi, jantung, stroke, asam urat, kolesterol, dll. telah menjadi trauma bagi sebagian masyarakat. Hikmah dari fenomena tersebut telah menumbuhkan kesadaran pada diri masyarakat untuk kembali menikmati makanan yang memiliki standar kualitas sehat dan baik.

Jawaban atas kegundahan tersebut sebenarnya telah dimiliki oleh ajaran agama Islam. Bersumber pada Alquran, ada 31 ayat yang merujuk pada konsep halal. Adapun ayat yang secara eksplisit merujuk kepada makanan dan minuman ada 16 ayat. Salah satu di antaranya adalah

\section{QS Al Baqarah: 168.}

Hai sekalian manusia, makanlah yang halal lagi baik dari apa yang terdapat di bumi, dan janganlah kamu mengikuti langkah-langkah syaitan; karena sesungguhnya syaitan itu adalah musuh yang nyata bagimu.

\section{QS Ali Imran: 93 (makanan halal bani Israil).}

Semua makanan adalah halal bagi Bani Israil melainkan makanan yang diharamkan oleh Israil (Ya'qub) untuk dirinya sendiri sebelum Taurat diturunkan. Katakanlah: "(Jika kamu mengatakan ada makanan yang diharamkan sebelum turun Taurat), maka bawalah Taurat itu, lalu bacalah dia jika kamu orang-orang yang benar".

QS Al Maidah: 5 (makanan sembelihan).

Pada hari ini dihalalkan bagimu yang baik-baik. Makanan (sembelihan) orang-orang yang diberi Al Kitab itu halal bagimu, dan makanan kamu halal (pula) bagi mereka. (Dan dihalalkan mangawini) wanita yang menjaga kehormatan diantara wanita-wanita yang beriman dan wanitawanita yang menjaga kehormatan di antara orang-orang yang diberi Al Kitab sebelum kamu, bila kamu telah membayar mas kawin mereka dengan maksud menikahinya, tidak dengan maksud berzina dan tidak (pula) menjadikannya gundik-gundik. Barangsiapa yang kafir sesudah beriman (tidak menerima hukum-hukum Islam) maka hapuslah amalannya dan ia di hari kiamat termasuk orang-orang merugi.

\section{QS Al Maidah: 88 (makanan halal dan baik).}

Dan makanlah makanan yang halal lagi baik dari apa yang Allah telah rezekikan kepadamu, dan bertakwalah kepada Allah yang kamu beriman kepada-Nya.

\section{QS Al Anfaal: 69 (perolehan makanan).}

Maka makanlah dari sebagian rampasan perang yang telah kamu ambil itu, sebagai makanan yang halal lagi baik, dan bertakwalah kepada Allah; sesungguhnya Allah Maha Pengampun lagi Maha Penyayang. 
QS An Nahl: 114 (makanan halal dan baik).

Maka makanlah yang halal lagi baik dari rezeki yang telah diberikan Allah kepadamu; dan syukurilah nikmat Allah, jika kamu hanya kepada-Nya saja menyembah.

QS Al Baqarah: 275 (perolehan makanan).

Orang-orang yang makan (mengambil) riba tidak dapat berdiri melainkan seperti berdirinya orang yang kemasukan syaitan lantaran (tekanan) penyakit gila. Keadaan mereka yang demikian itu, adalah disebabkan mereka berkata (berpendapat), sesungguhnya jual beli itu sama dengan riba, padahal Allah telah menghalalkan jual beli dan mengharamkan riba. Orang-orang yang telah sampai kepadanya larangan dari Tuhannya, lalu terus berhenti (dari mengambil riba), maka baginya apa yang telah diambilnya dahulu (sebelum datang larangan); dan urusannya (terserah) kepada Allah. Orang yang kembali (mengambil riba), maka orang itu adalah penghuni-penghuni neraka; mereka kekal di dalamnya.

QS An Nisaa: 160 (penghalalan dan pengharaman makanan).

Maka disebabkan kezaliman orang-orang Yahudi, kami haramkan atas (memakan makanan) yang baik-baik (yang dahulunya) dihalalkan bagi mereka, dan karena mereka banyak menghalangi (manusia) dari jalan Allah.

QS Al Maidah: 1 (makanan binatang ternak perolehan berburu).

Hai orang-orang yang beriman, penuhilah aqad-aqad itu. Dihalalkan bagimu binatang ternak, kecuali yang akan dibacakan kepadamu. (Yang demikian itu) dengan tidak menghalalkan berburu ketika kamu sedang mengerjakan haji. Sesungguhnya Allah menetapkan hukum-hukum menurut yang dikehendaki-Nya.

QS Al Maidah: 4 (makanan buruan).

Mereka menanyakan kepadamu: "Apakah yang dihalalkan bagi mereka?". Katakanlah: "Dihalalkan bagimu yang baik-baik dan (buruan yang ditangkap) oleh binatang buas yang telah kamu ajar dengan melatih nya untuk berburu; kamu mengajarnya menurut apa yang telah diajarkan Allah kepadamu. Maka makanlah dari apa yang ditangkapnya untukmu, dan sebutlah nama Allah atas binatang buas itu (waktu melepaskannya). Dan bertakwalah kepada Allah, sesungguhnya Allah amat cepat hisab-Nya.

QS Al Maidah: 87 (penghalalan dan pengharaman).

Hai orang-orang yang beriman, janganlah kamu haramkan apa-apa yang baik yang telah Allah halalkan bagi kamu, dan janganlah kamu melampaui batas. Sesungguhnya Allah tidak menyukai orang-orang yang melampaui batas. 
QS Al Maidah: 96 (makanan buruan laut dan darat).

Dihalalkan bagimu binatang buruan laut dan makanan (yang berasal) dari laut sebagai makanan yang lezat bagimu, dan bagi orang-orang yang dalam perjalanan; dan diharamkan atasmu (menangkap) binatang buruan darat, selama kamu dalam ihram. Dan bertakwalah kepada Allah Yang kepada-Nya-lah kamu akan dikumpulkan.

QS Al An'am: 118 (proses penyembelihan binatang yang halal).

Maka makanlah binatang-binatang (yang halal) yang disebut nama Allah ketika menyembelihnya, jika kamu beriman kepada ayat-ayat-Nya.

QS Al An'am: 119 (Pengharaman atas yang makanan binatang halal). Mengapa kamu tidak mau memakan (binatang-binatang yang halal) yang disebut nama Allah ketika menyembelihnya, padahal sesungguhnya Allah telah menjelaskan kepada kamu apa yang diharamkan-Nya atasmu, kecuali apa yang terpaksa kamu memakannya. Dan sesungguhnya kebanyakan (dari manusia) benar benar hendak menyesatkan (orang lain) dengan hawa nafsu mereka tanpa pengetahuan. Sesungguhnya Tuhanmu, Dialah yang lebih mengetahui orang-orang yang melampaui batas.

QS Yunus: 59 (makanan halal dan haram).

Katakanlah: "Terangkanlah kepadaku tentang rezeki yang diturunkan Allah kepadamu, lalu kamu jadikan sebagiannya haram dan (sebagiannya) halal". Katakanlah: "Apakah Allah telah memberikan izin kepadamu (tentang ini) atau kamu mengada-adakan saja terhadap Allah?"

\section{QS Al Hajj: 30 (binatang ternak kecuali yang diterangkan keharamannya). \\ Demikianlah (perintah Allah). Dan barangsiapa mengagungkan apa-apa yang terhormat di sisi Allah maka itu adalah lebih baik baginya di sisi Tuhannya. Dan telah dihalalkan bagi kamu semua binatang ternak, terkecuali yang diterangkan kepadamu keharamannya, maka jauhilah olehmu berhala-berhala yang najis itu dan jauhilah perkataan-perkataan dusta.}

Berikut ini penjelasan terkait terminologi halal, haram, dan toyib. Secara makna halal bermakna dibenarkan. Istilah haram artinya dilarang, atau tidak dibenarkan menurut syariat Islam. Adapun toyib mengandung arti bermutu dan tidak membahayakan kesehatan.

Dengan demikian, konsep halal dan toyib pada makanan dan minuman adalah dua hal yang tidak bisa dipisahkan bagi umat manusia. Islam sangat memperhatikan aspek syariat dan kulitas/ mutu makanan yang tujuannya adalah menyelamatkan dan menyehatkan diri manusia.

Selain itu, penulis temukan tidak kurang dari 63 ayat terkait keharaman. Dari jumlah tersebut terdapat 17 ayat di antaranya berkaitan dengan makanan dan minuman haram. Ayat yang dimaksud adalah sebagai berikut. 


\section{QS Al Baqarah: 173}

Sesungguhnya Allah hanya mengharamkan bagimu bangkai, darah, daging babi, dan binatang yang (ketika disembelih) disebut (nama) selain Allah. Tetapi barangsiapa dalam keadaan terpaksa (memakannya) sedang dia tidak menginginkannya dan tidak (pula) melampaui batas, maka tidak ada dosa baginya. Sesungguhnya Allah Maha Pengampun lagi Maha Penyayang.

\section{QS Ali Imran: 93}

Semua makanan adalah halal bagi Bani Israil melainkan makanan yang diharamkan oleh Israil (Ya'qub) untuk dirinya sendiri sebelum Taurat diturunkan. Katakanlah: "(Jika kamu mengatakan ada makanan yang diharamkan sebelum turun Taurat), maka bawalah Taurat itu, lalu bacalah dia jika kamu orang-orang yang benar".

\section{QS Al Maidah: 3}

Diharamkan bagimu (memakan) bangkai, darah, daging babi, (daging hewan) yang disembelih atas nama selain Allah, yang tercekik, yang terpukul, yang jatuh, yang ditanduk, dan diterkam binatang buas, kecuali yang sempat kamu menyembelihnya, dan (diharamkan bagimu) yang disembelih untuk berhala. Dan (diharamkan juga) mengundi nasib dengan anak panah, (mengundi nasib dengan anak panah itu) adalah kefasikan. Pada hari ini orang-orang kafir telah putus asa untuk (mengalahkan) agamamu, sebab itu janganlah kamu takut kepada mereka dan takutlah kepada-Ku. Pada hari ini telah Kusempurnakan untuk kamu agamamu, dan telah Ku-cukupkan kepadamu nikmat-Ku, dan telah Ku-ridhai Islam itu jadi agama bagimu. Maka barang siapa terpaksa karena kelaparan tanpa sengaja berbuat dosa, sesungguhnya Allah Maha Pengampun lagi Maha Penyayang.

\section{QS Al Maidah: 42}

Mereka itu adalah orang-orang yang suka mendengar berita bohong, banyak memakan yang haram. Jika mereka (orang Yahudi) datang kepadamu (untuk meminta putusan), maka putuskanlah (perkara itu) diantara mereka, atau berpalinglah dari mereka; jika kamu berpaling dari mereka maka mereka tidak akan memberi mudharat kepadamu sedikitpun. Dan jika kamu memutuskan perkara mereka, maka putuskanlah (perkara itu) diantara mereka dengan adil, sesungguhnya Allah menyukai orangorang yang adil.

\section{QS Al Maidah: 62}

Dan kamu akan melihat kebanyakan dari mereka (orang-orang Yahudi) bersegera membuat dosa, permusuhan dan memakan yang haram. Sesungguhnya amat buruk apa yang mereka telah kerjakan itu. 


\section{QS Al Maidah: 63}

Mengapa orang-orang alim mereka, pendeta-pendeta mereka tidak melarang mereka mengucapkan perkataan bohong dan memakan yang haram? Sesungguhnya amat buruk apa yang telah mereka kerjakan itu.

\section{QS Al Maidah: 96}

Dihalalkan bagimu binatang buruan laut dan makanan (yang berasal) dari laut sebagai makanan yang lezat bagimu, dan bagi orang-orang yang dalam perjalanan; dan diharamkan atasmu (menangkap) binatang buruan darat, selama kamu dalam ihram. Dan bertakwalah kepada Allah Yang kepada-Nya-lah kamu akan dikumpulkan.

\section{QS Al An'am: 138}

Dan mereka mengatakan: "Inilah hewan ternak dan tanaman yang dilarang; tidak boleh memakannya, kecuali orang yang kami kehendaki", menurut anggapan mereka, dan ada binatang ternak yang diharamkan menungganginya dan ada binatang ternak yang mereka tidak menyebut nama Allah waktu menyembelihnya, semata-mata membuat-buat kedustaan terhadap Allah. Kelak Allah akan membalas mereka terhadap apa yang selalu mereka ada-adakan.

\section{QS Al An'am: 139}

Dan mereka mengatakan: "Apa yang ada dalam perut binatang ternak ini adalah khusus untuk pria kami dan diharamkan atas wanita kami," dan jika yang dalam perut itu dilahirkan mati, maka pria dan wanita sama-sama boleh memakannya. Kelak Allah akan membalas mereka terhadap ketetapan mereka. Sesungguhnya Allah Maha Bijaksana lagi Maha Mengetahui.

\section{QS Al An'am:140}

Sesungguhnya rugilah orang yang membunuh anak-anak mereka, karena kebodohan lagi tidak mengetahui dan mereka mengharamkan apa yang Allah telah rezeki-kan pada mereka dengan semata-mata mengada-adakan terhadap Allah. Sesungguhnya mereka telah sesat dan tidaklah mereka mendapat petunjuk.

\section{QS Al An'am:143 )}

(yaitu) delapan binatang yang berpasangan, sepasang domba, sepasang dari kambing. Katakanlah: "Apakah dua yang jantan yang diharamkan Allah ataukah dua yang betina, ataukah yang ada dalam kandungan dua betinanya?" Terangkanlah kepadaku dengan berdasar pengetahuan jika kamu memang orang-orang yang benar,

\section{QS Al An'am: 144}

Dan sepasang dari unta dan sepasang dari lembu. Katakanlah: "Apakah dua yang jantan yang diharamkan ataukah dua yang betina, ataukah yang 
ada dalam kandungan dua betinanya? Apakah kamu menyaksikan di waktu Allah menetapkan ini bagimu? Maka siapakah yang lebih zalim daripada orang-orang yang membuat-buat dusta terhadap Allah untuk menyesatkan manusia tanpa pengetahuan?" Sesungguhnya Allah tidak memberi petunjuk kepada orang-orang yang zalim.

\section{QS Al An'am: 145}

Katakanlah: "Tiadalah aku peroleh dalam wahyu yang diwahyukan kepadaku, sesuatu yang diharamkan bagi orang yang hendak memakannya, kecuali kalau makanan itu bangkai, atau darah yang mengalir atau daging babi -- karena sesungguhnya semua itu kotor -- atau binatang yang disembelih atas nama selain Allah. Barangsiapa yang dalam keadaan terpaksa, sedang dia tidak menginginkannya dan tidak (pula) melampaui batas, maka sesungguhnya Tuhanmu Maha Pengampun lagi Maha Penyayang".

\section{QS Al An'am:146}

Dan kepada orang-orang Yahudi, Kami haramkan segala binatang yang berkuku dan dari sapi dan domba, Kami haramkan atas mereka lemak dari kedua binatang itu, selain lemak yang melekat di punggung keduanya atau yang di perut besar dan usus atau yang bercampur dengan tulang. Demikianlah Kami hukum mereka disebabkan kedurhakaan mereka; dan sesungguhnya Kami adalah Maha Benar.

\section{QS Al An'am: 148}

Orang-orang yang mempersekutukan Tuhan, akan mengatakan: "Jika Allah menghendaki, niscaya kami dan bapak-bapak kami tidak mempersekutukan-Nya dan tidak (pula) kami mengharamkan barang sesuatu apapun". Demikian pulalah orang-orang sebelum mereka telah mendustakan (para rasul) sampai mereka merasakan siksaan Kami. Katakanlah: "Adakah kamu mempunyai sesuatu pengetahuan sehingga dapat kamu mengemukakannya kepada Kami?" Kamu tidak mengikuti kecuali persangkaan belaka, dan kamu tidak lain hanyalah berdusta.

\section{QS Al An'am: 150}

Katakanlah: "Bawalah kemari saksi-saksi kamu yang dapat mempersaksikan bahwasanya Allah telah mengharamkan (makanan yang kamu) haramkan ini" Jika mereka mempersaksikan, maka janganlah kamu ikut pula menjadi saksi bersama mereka; dan janganlah kamu mengikuti hawa nafsu orang-orang yang mendustakan ayat-ayat Kami, dan orangorang yang tidak beriman kepada kehidupan akhirat, sedang mereka mempersekutukan Tuhan mereka.

\section{QS An Nahl: 115}

Sesungguhnya Allah hanya mengharamkan atasmu (memakan) bangkai, darah, daging babi dan apa yang disembelih dengan menyebut nama selain 
Allah; tetapi barangsiapa yang terpaksa memakannya dengan tidak menganiaya dan tidak pula melampaui batas, maka sesungguhnya Allah Maha Pengampun lagi Maha Penyayang.

Rofi'i (2010: Tersedia: http://www.halalmuibali.or.id/?p=56 November 2016]) menjelaskan lebih lanjut bahwa "Dalam ajaran Islam, semua jenis makanan dan minuman pada dasarnya adalah halal, kecuali hanya beberapa saja yang diharamkan. Yang haram itupun menjadi halal bila dalam keadaan darurat. Sebaliknya, yang halal pun bisa menjadi haram bila dikonsumsi melampaui batas." Ditegaskannya pula bahwa pemahaman halal dan haram ini termasuk pula pada aspek perbuatan.

Mengacu pada sejumlah keterangan, pemaknaan makanan dan minuman halal dalam ajaran Islam meliputi aspek-aspek berikut: (1) dzatnya, (2) cara memprosesnya, dan (3) cara memperolehnya. Adapun hikmah adanya makanan dan minuman halal dan haram yang diberlakukan pada umat manusia, pada hakikatnya untuk: (1) jadi bahan ujian keimanan dan ketakwaan manusia; (2) upaya perlindungan kesehatan manusia; serta (3) upaya menjauhkan dari perilaku yang buruk mengingat antara dzat, proses, dan perolehannya terdapat hubungan yang signifikan terhadap kualitas spiritual pribadinya.

\section{METODOLOGI PENELITIAN}

Metode penelitian yang penulis gunakan dalam penelitian kali ni adalah metode kualitatif. Untuk mendapatkan pemahaman yang lebih luas dan mendalam terhadap situasi sosial yang diteliti, teknik pengumpulan data bersifat triangulasi, yaitu menggunakan berbagai teknik pengumpulan data secara simultan. Analisis data yang dilakukan bersifat induktif berdasarkan fakta-fakta yang ditemukan di lapangan dan kemudian dikonstruksikan menjadi hipotesis atau teori. Metode deskriptif digunakan untuk mendapatkan data yang mendalam, suatu data yang mengandung makna. Makna adalah daya yang sebenarnya, data yang pasti merupakan suatu nilai dibalik data yang tampak.

Oleh karena itu, dalam penelitian kualitatif tidak menekankan pada generalisasi, tetapi lebih menekankan pada makna. Generalisasi dalam penelitian kualitatif dinamakan transferability. Unsur-unsur yang dideskripsikan dalam penelitian ini meliputi: (1) ragam kuliner tradisional di Desa Pakuwonr, (2) teknik pengolahan kuliner tradisional di Desa Pakuwon, (3) konteks pembuatan dan penyajian kuliner tradisional Desa Pakuwon, dan (4) kehalalan kuliner tradisional Desa Pakuwon.

Populasi adalah keseluruhan subjek penelitian (Arikunto, 2002:108). Berdasarkan penjelasan di atas, populasi dalam penelitian ini adalah kuliner berikut para nara sumber di kawasan Desa Pakuwon, Kecamatan Cisurupan, Kabupaten Garut.

Sampel dalam penelitian ini adalah berbagai kuliner dan narasumber di kawasan Kampung Sindang Daweung, Desa Pakuwon. Pengambilan sampel tersebut lebih menititikberatkan pada Kampung Sindang Daweung karena 
kawasan tersebut sebagai salah satu kawasan destinasi utama wisata yang ada di desa tersebut.

Teknik yang digunakan peneliti dalam mengumpulkan data antara lain observasi, wawancara, dan studi dokumentasi. Pengamatan (observasi) yang dibantu melalui media visual/audiovisual. Pengobservasian dalam penelitian ini penulis lakukan dengan melihat secara langsung pada saat kuliner tersebut dibuat dan disajikan oleh para narasumber. Selain itu, penulis pun berperan aktif sebagai partisipan pada saat pembuatan dan penyajian, sekaligus menjadi penikmat kuliner tersebut.

Adapun para narasumber yang berhasil penulis temui dan wawancarai adalah mereka yang dalam keseharian sebagai praktisi dan dianggap memiliki kecakapan, keterampilan, dan pengetahuan dalam membuat dan menyajikan kuliner. Mereka rata-rata adalah para ibu rumah tangga sekaligus figur yang menjadi rujukan masyarakat di sekitarnya.

Peneliti menggunakan studi dokumentasi untuk memeroleh data secara utuh dan lengkap, melalui sejumlah literatur/ naskah, foto, dan data sekunder seperti data demografi penduduk, data kebudayaan, data kepariwisatawan dan sebagainya. Dokumentasi bisa berbentuk tulisan, gambar, atau karya-karya monumental dari seseorang.

Dalam penelitian ini, peneliti menggunakan beberapa instrumen yang digunakan untuk mengumpulkan data, sebagai berikut: daftar periksa, pedoman wawancara, dan dokumen.

Teknik analisis yang digunakan adalah analisis statistik deskriptif. Menurut Kusmayadi (2004:25) statistik deskriptif adalah ilmu statistik yang mempelajari bagaimana cara mengumpulkan data, menggolong-golongkan data, menyimpulkan, dan menyajikan dalam bentuk yang lebih ringkas dan jelas ke dalam tabel, grafik, dan gambar.

\section{HASIL DAN PEMBAHASAN}

Berdasarkan ketersediaan data kuliner yang ada di Desa Pakuwon akhirnya penulis dapat menginventarisasi 189 jenis kuliner. Keseluruhan jenis kuliner tersebut lalu penulis kategorikan ke dalam: (1) makanan pokok, (2) sup, (3) laukpauk, (4) lalab, (5) sambal, (6) kerupuk/ keripik, (7) kudapan, dan (8) bubur Selanjutnya penulis sampaikan data lengkap dalam tabel di bawah ini:

Tabel 1.

Kategori dan Ragam Kuliner di Desa Pakuwon, Kecamaatan Cisurupan, Kabupaten Garut

\begin{tabular}{|l|l|l|c|c|}
\hline No. & Kategori & Ragam & Jumlah & $\%$ \\
\hline 1 & Makanan pokok & $\begin{array}{l}\text { M5, M100, M101, M111, M112, } \\
\text { M113, M114, M136, M169, } \\
\text { M170, M171, M172, M183, } \\
\text { M184, M187, M189 }\end{array}$ & 17 & 9 \\
\hline 2 & Sup & M6, M7, M8, M9, M10, M174 & 6 & 3 \\
\hline
\end{tabular}




\begin{tabular}{|c|c|c|c|c|}
\hline 3 & Lauk-pauk & $\begin{array}{l}\text { M2, M3, M5, M13, M14, M15, } \\
\text { M17, M20, M21, M33, M43, } \\
\text { M44, M50, M51, M52, M54, } \\
\text { M57, M58, M59, M60, M61, } \\
\text { M66, M72, M75, M76, M77, } \\
\text { M81, M110, M115, M116, } \\
\text { M117, M129, M130, M131, } \\
\text { M132, M133, M135, M137, } \\
\text { M138, M139, M148, M150, } \\
\text { M173, M174. M186 }\end{array}$ & 45 & 23,8 \\
\hline 4 & Lalab & $\begin{array}{l}\text { M24, M32, M45, M46, M47, } \\
\text { M109 }\end{array}$ & 6 & 3 \\
\hline 5 & Sambal & $\begin{array}{l}\text { M156, M157, M158, M159, } \\
\text { M160, M161, M162, M163, } \\
\text { M164, M165, M166, M167, } \\
\text { M168 }\end{array}$ & 13 & 6,8 \\
\hline 6 & Kerupuk/ keripik & $\begin{array}{l}\text { M84, M85, M86, M87, M88, } \\
\text { M102, M103, M104, M105, } \\
\text { M106, M106, M107, M108, } \\
\text { M126, M127, M143, M144 }\end{array}$ & 17 & 9 \\
\hline 7 & Makanan kudapan & $\begin{array}{l}\text { M1, M2, M4, M11, M12, M16, } \\
\text { M17, M18, M19, M22, M23, } \\
\text { M25, M26, M27, M28, M29, } \\
\text { M30, M31, M34, M35, M36, } \\
\text { M37, M38, M39, M40, M41, } \\
\text { M42, M48, M49, M53, M54, } \\
\text { M55, M56, M62, M63, M64, } \\
\text { M65, M67, M68, M69, M70, } \\
\text { M71, M73, M74, M77, M78, } \\
\text { M79, M80, M82, M83, M89, } \\
\text { M90, M91, M92, M93, M94, } \\
\text { M95, M96, M97, M98, M99, } \\
\text { M118, M119, M120, M121, } \\
\text { M122, M123, M124, M125, } \\
\text { M128, M134, M140, M141, } \\
\text { M142, M145, M146, M147, } \\
\text { M149. M150, M151, M152, } \\
\text { M153, M154, M155, M176, } \\
\text { M177, M178, M179, M180, } \\
\text { M181, M182, M185, M187, } \\
\text { M189 }\end{array}$ & 114 & 60,3 \\
\hline 8 & Bubur & M26, M27, M28, M29, M30 & 5 & 2,6 \\
\hline
\end{tabular}

Sebagaimana yang kita ketahui bahwa ragam kuliner di Desa Pakuwon mencapai 189 jenis. Keragaman ini menyebar ke delapan kategori utama seperti yang penulis sampaikan sebelumnya. Dari jumlah ini ada pula beberapa jenis 
makanan masuk pada dua atau tiga kategori sekaligus. Oleh karenanya data yang penulis kemukakan pada dasarnya sudah terdistribusikan.

Berdasarkan data sebaran akhirnya penulis menemukan, bahwa ragam kuliner pada kategori kudapan lebih menonjol tinimbang kategori lainnya $(60,3 \%)$. Urutan kedua adalah lauk-pauk $(23,9 \%)$, urutan ketiga ditempati kategori makanan pokok dan kerupuk atau keripik $(9 \%)$, urutan keempat sup dan lalab (3\%), dan urutan kelima adalah bubur $(2,6 \%)$.

Jika melihat pada fenomena kudapan di atas, penulis berkesimpulan bahwa masyarakat memiliki selera kudapan cukup tinggi dengan berbagai varian yang sangat banyak yaitu 114 jenis. Ini membuktikan kreativitas dan inovasi mereka dalam mengolah makanan sangat baik. Di samping itu, ragam kudapan yang ada dalam khazanah kuliner tradisional di desa tersebut sekarang mulai bertambah dengan masuknya ragam kue biskuit yang merupakan produk budaya yang datang dari Eropa yang dibawa dari kota.

Terkait dengan lalaban, di sini perlu penulis sampaikan bahwa jumlah varietas tanaman yang dijadikan lalab dan dikonsumsi sehari-hari oleh masyarakat desa itu mencapai 32 jenis. Tanaman tersebut meliputi tanaman yang dibudidayakan maupun yang sifatnya liar di alam sekitarnya. Cara mengonsumsinya biasanya dilakukan dengan cara mentah/ langsung, dikukus, atau direbus terlebih dahulu.

Di antara ragam kuliner yang berhasil penulis inventarisasi disinyalir ada makanan yang merupakan khas dari daerah tersebut seperti bangkerok, boreleng, bubur hanjeli yang sudah jarang, ciwi, godeblag, ketan kue satu, jetruk, rujak jantung cau, mayang mekar, kurupuk kadedemes, kalua terong, kembang pala, sagon lulun, kurupuk genar, manisan cabe, manisan terong, sambel honje, tengteng ketan, dan borondong. Jenis makanan ini bisa dikembangkan menjadi ikon kuliner di desa ini, bahkan bila masyrakatnya lebih kreatif lagi sebenarnya masih banyak yang bisa diciptakan dengan memanfaatkan seluruh potensi pertanian yang ada di daerah ini.

Selanjutnya, penulis akan menyampaikan analisisan tentang sejumlah teknik yang dipergunakan dalam pengolahan kuliner yang ada di desa tersebut. Analisisan ini dilakukan dengan membandingkan data aktual lapangan dengan data inventarisasi yang telah dilakukan dalam penelitian sebelumnya.

Tabel 2.

Jenis Teknik Pengolahan Kuliner \& Frekuensi Pemakaiannya di Desa Pakuwon, Kecamatan Cisurupan, Kabupaten Garut

\begin{tabular}{|l|l|l|c|c|}
\hline No. & Teknik (Darwis, 1995) & Teknik (Darwis, 2016) & F & $\%$ \\
\hline 1 & \multicolumn{1}{|c|}{3} & 4 & 5 \\
\hline 1 & Diasinan (T1), & Diasinan & 3 & 0,6 \\
\hline 2 & $\begin{array}{l}\text { Dibakar/ dibeuleum } \\
\text { (T2) }\end{array}$ & Dibakar & 12 & 2,5 \\
\hline 3 & Dibubur (T3) & Dibubur & 5 & 1 \\
\hline 4 & Dibibis (T4) & Dibibis & 4 & 0,8 \\
\hline
\end{tabular}


Volume 2 Nomor 2 Juni 2017

\begin{tabular}{|c|c|c|c|c|}
\hline 5 & $\begin{array}{ll}\text { Dibubuy/ mubuy/ } & \text { Dibubus(T5) } \\
\text { Dibula }\end{array}$ & Dibubuy & 1 & 0,2 \\
\hline 6 & Diceos/ gejos (T6) & & & \\
\hline 7 & Dicobek (T7) & & & \\
\hline 8 & Diempos (T8) & & & \\
\hline 9 & Dieumping (T9) & & & \\
\hline 10 & Diganggang (T10) & Diganggang & 1 & 0,2 \\
\hline 11 & Digarang (T11) & & & \\
\hline 12 & $\begin{array}{l}\text { Digeprek/ geprak } \\
\text { (T12) }\end{array}$ & Digeprek & 1 & 0,2 \\
\hline 13 & Digigihan (T13) & Digigihan & 6 & 1,2 \\
\hline 14 & Digoreng ((T14) & Digoreng & 53 & 11,1 \\
\hline 15 & Dijemur/ poe (T15) & Dijemur & 25 & 5,2 \\
\hline 16 & Dikarih (T16) & Dikarih & 8 & 1,7 \\
\hline 17 & $\begin{array}{ll}\text { Dikere/ } & \text { deeng/ } \\
\text { dendeng (T17) }\end{array}$ & Dikere & 2 & 0,4 \\
\hline 18 & $\begin{array}{l}\text { Dileumpeuhkeun } \\
\text { (T18) }\end{array}$ & & & \\
\hline 19 & Dileumeung (T19) & & & \\
\hline 20 & Diliwet (T20) & Diliwet & 2 & 0,4 \\
\hline 21 & Dimanisan (T21) & Dimanisan & 14 & 2,9 \\
\hline 22 & Dipais (T22) & Dipais & 8 & 1,7 \\
\hline 23 & Dipeuyeum (T23) & Dipeuyeum & 1 & 0,2 \\
\hline 24 & Dipindang (T24) & & & \\
\hline 25 & Dirarameusan (T25) & & & \\
\hline 26 & $\begin{array}{ll}\begin{array}{l}\text { Direbus/ } \\
\text { (T26) }\end{array} & \text { digodog } \\
\end{array}$ & Direbus & 58 & 12,2 \\
\hline 27 & Direndos (T27), & Diulek & 24 & 5 \\
\hline 28 & $\begin{array}{l}\text { Direndam/ dikeueum } \\
\text { (T28) }\end{array}$ & Direndam & 10 & 2,1 \\
\hline 29 & Direrab (T29) & & & \\
\hline 30 & $\begin{array}{l}\text { Diruum/ diruruum/ } \\
\text { diseuseungit/ } \\
\text { diwangikan (T30) }\end{array}$ & Diseusengit & 11 & 2,3 \\
\hline 31 & Disangray (T31) & Disangray & 10 & 2,1 \\
\hline 32 & Disemur (T32) & & & \\
\hline 33 & $\begin{array}{l}\text { Diseupan/ dikukus } \\
\text { (T33) }\end{array}$ & $\begin{array}{l}\text { Ditanak } \\
\text { Dikukus }\end{array}$ & $\begin{array}{c}9 \\
37 \\
\end{array}$ & $\begin{array}{l}1,9 \\
7,8\end{array}$ \\
\hline 34 & $\begin{array}{l}\text { Ditumbuk/ ditutu } \\
\text { (T34) }\end{array}$ & Ditumbuk & 18 & 3,8 \\
\hline 35 & Ditumis (T35) & Ditumis & 14 & 2,9 \\
\hline 36 & Ditutug (T36) & & & \\
\hline 37 & Dituum (T37) & & & \\
\hline 38 & $\begin{array}{l}\text { Dituuskeun/ ditiriskan } \\
\text { (T38) }\end{array}$ & & & \\
\hline
\end{tabular}


Touriem Scientific Dournal

Volume 2 Nomor 2 Juni 2017

\begin{tabular}{|c|c|c|c|c|}
\hline 39 & Diunun (T39) & & & \\
\hline 40 & Diungkeb (T40) & Diungkeb & 2 & 0,4 \\
\hline 41 & & Diakeul & 4 & 0,8 \\
\hline 42 & & Dibentuk & 6 & 1,2 \\
\hline 43 & & Dibungkus & 2 & 0,4 \\
\hline 44 & & Dicetak & 18 & 3,8 \\
\hline 45 & & Didadar & 3 & 0,6 \\
\hline 46 & & Didage & 1 & 0,2 \\
\hline 47 & & Diglasur & 1 & 0,2 \\
\hline 48 & & Digulai & 3 & 0,6 \\
\hline 49 & & Diiris & 16 & 3,3 \\
\hline 50 & & Dikaredok & 2 & 0,4 \\
\hline 51 & & Dikentalkan & 1 & 0,2 \\
\hline 52 & & Dikerok & 1 & 0,2 \\
\hline 53 & & Dikipasi & 4 & 0,8 \\
\hline 54 & & Dikocok & 2 & 0,4 \\
\hline 55 & & Dikolek & 6 & 1,2 \\
\hline 56 & & Dimasak & 1 & 0,2 \\
\hline 57 & & Diparut pasrah/ diisrud & 4 & 0,8 \\
\hline 58 & & Diparut & 15 & 3,1 \\
\hline 59 & & Dipepes & 2 & 0,4 \\
\hline 60 & & Dipindang & 2 & 0,4 \\
\hline 61 & & Dipotong & 7 & 1,5 \\
\hline 62 & & Dirujak & 6 & 1,2 \\
\hline 63 & & Disate & 2 & 0,4 \\
\hline 64 & & Diseduh & 7 & 1,5 \\
\hline 65 & & Diserut & 3 & 0,6 \\
\hline 66 & & Disup & 5 & 1 \\
\hline 67 & & Langsung & 5 & 1 \\
\hline 68 & & Multiteknik & 2 & 0,4 \\
\hline 69 & & Dipanggang & 5 & 1 \\
\hline
\end{tabular}

Berdasarkan data bandingan penelitian Darwis (1995) yang berjumlah 40 teknik, penulis pada akhirnya melihat adanya temuan bahwa dalam budaya kuliner masyarakat Sunda sekarang bertambah menjadi 69 teknik. Pada era sekarang ada tidak kurang dari 55 teknik yang dipakai. Bila ditelusuri bandingan data 1995 dengan yang terkini masih ada 26 teknik pengolahan yang masih dilakukan oleh masyarakat dan 16 teknik sudah tidak atau jarang dipakai lagi.

Kembali pada data 189 ragam kuliner yang berkembang dan dipakai di kalangan masyarakat Desa Pakuwon, pada akhirnya penulis menemukan fakta bahwa teknik pengolahan yang dipakai berentang dari $1-\mathrm{x} \geq 8$ teknik sekaligus. Untuk lebih jelasnya penulis paparkan dalam tabel berikut. 
Tabel 3.

Distribusi Frekuensi Teknik Pengolahan dalam Ragam Kuliner di Desa Pakuwon, Kecamatan Cisurupan, Kabupaten Garut

\begin{tabular}{|c|c|c|c|c|}
\hline No. & $\begin{array}{c}\text { Jumlah } \\
\text { Teknik yang } \\
\text { Dipakai }\end{array}$ & Ragam Kuliner & $\mathrm{F}$ & $\%$ \\
\hline 1 & 1 & 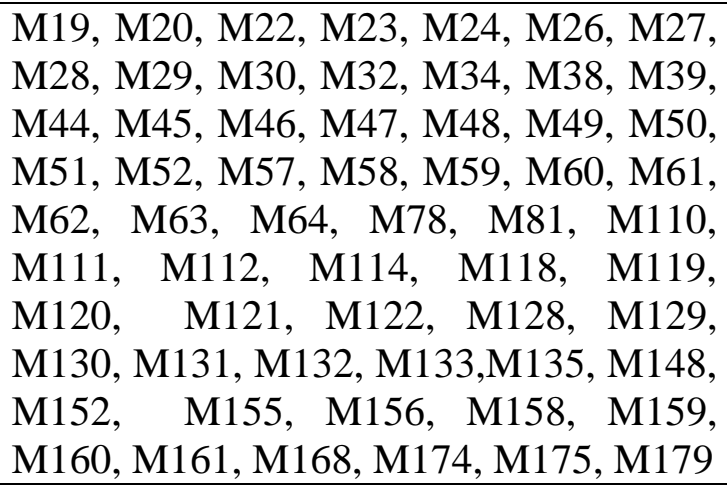 & 61 & 32,3 \\
\hline 2 & 2 & $\begin{array}{l}\text { M4, M5, M6, M8, M9, M12, M13, M15, } \\
\text { M16, M17, M21, M25, M31, M33, M35, } \\
\text { M37, M42, M53, M54, M65, M67, M68, } \\
\text { M69, M71, M72, M77, M79, M85, M98, } \\
\text { M99, M100, M109, M115, M125, M127, } \\
\text { M142, M146, M149, M153, M161, } \\
\text { M162, M163, M177, M178, M184, M183 }\end{array}$ & 46 & 24,3 \\
\hline 3 & 3 & $\begin{array}{l}\text { M7, M10, M11, M41, M55, M56, M70, } \\
\text { M73, M74, M75, M76, M80, M82, M83, } \\
\text { M86, M87, M96, M116, M117, M124, } \\
\text { M134, M140, M145, M150, M151, } \\
\text { M165, M166, M172, M176 }\end{array}$ & 29 & 15,3 \\
\hline 4 & 4 & 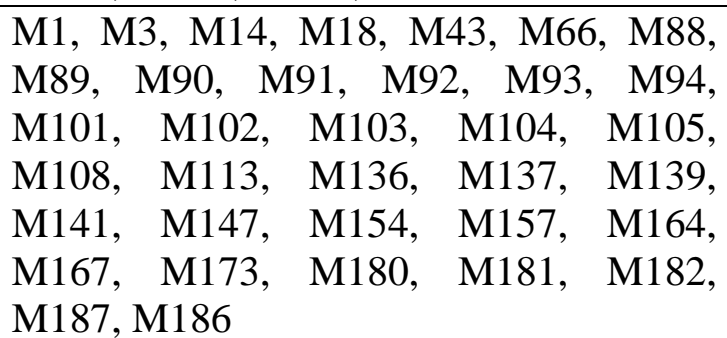 & 35 & 18,5 \\
\hline 5 & 5 & $\begin{array}{l}\text { M84, M97, M106, M138, M144, M143, } \\
\text { M169, M170, M171, }\end{array}$ & 9 & 4,8 \\
\hline 6 & 6 & M95, M126, M188 & 3 & 1,6 \\
\hline 7 & 7 & M185 & 1 & 0,5 \\
\hline 8 & $X \geq 8$ & M2, M36, M107, M123, M189 & 5 & 2,6 \\
\hline
\end{tabular}

Dengan demikian, pada akhirmya penulis menemukan bahwa pemanfaatan teknik pengolahan kuliner dalam ragam masakan yang paling menonjol jumlahnya berentang dari urutan yang tertinggi adalah 1 teknik (32,3\%), 2 teknik (24,3\%), 4 
teknik (18,5\%), 3 teknik (15,3\%), 5 teknik (4,8\%), 5 teknik $(4,8 \%), X \geq 8$ teknik $(2,6 \%)$, dan 7 teknik $(0,5 \%)$.

Ulasan berikutnya adalah konteks pembuatan dan penyajian kuliner yang tumbuh dan berkembang di masyarakat. Berdasarkan hasil observasi dan wawancara yang penuls lakukan terhadap para narasumber diperoleh gambaran bahwa pembuatan dan penyajian kuliner terbagi atas rutinitas kebutuhan domestik keluarga (sarapan pagi, makan siang, makan malam, makanan penyela, kudapan), komersial, dan acara seremonial yang berupa adat ataupun keagamaan terkait pernikahan, kehamilan, kelahiran, kematian, keselamatan dan musibah, peringatan hari-hari keagamaan maupun hari-hari besar nasional sebagaimana telah disampaikan dalam subbab sebelumnya.

Adapun jumlah sajian makanan dalam konteks sehari-hari tidak kurang dari 6 kategori utama yaitu makanan pokok (nasi, liwet, kupat, ataupun yang lainnya), sambal (satu jenis), lalaban (minimal ada dua jenis), lauk-pauk (minimal ada dua jenis), kudapan (minimal ada satu jenis), dan kerupuk (minimal satu jenis). Namun demikian dalam upacara perhelatan seperti pernikahan ataupun sunatan 8 kategori utama makanan bisa disajikan semuanya jumlahnya bisa mencapai puluhan jenis makanan yang dihidangkan. Sebagai pemisalahan, dalam acara memberikan berkat (idangan) bagi tetangga minimal 12 macam makanan disatukan dalam satu paket hantaran.

Dengan demikian pembuatan dan penyajian kuliner di kawasan desa ini berbiaya cukup besar mengingat sejumlah materi sajian makanan yang demikian banyak. Meskipun demikian hal ini dapat tertanggulangi karena adanya sifat kegotongroyongan antarwarga dan antaranggota keluarga (kerabat, saudara) sang tuan rumah penyelenggara perhelatan.

Berdasarkan amatan terhadap sejumlah temuan di lapangan menyangkut kahalalan dari aspek material bahan, perolehan, proses, keamanan, higiene, dan sanitasi, akan penulis sampaikan sebagai berikut. Pertama dari aspek material bahan makanan hampir mendekati $100 \%$ halal mengingat masyarakat mayoritas muslim kalangan pesantren yang sangat tahu dan sadar dalam menyeleksi jenis makanan yang diperbolehkan dan diharamkan. Meskipun demikian wajib diwaspadai oleh masyarakat sekitar, bahwa ada beberapa bahan tambahan makanan (penyedap rasa) yang penulis amati mulai diminati para ibu rumah tangga. Hal ini perlu mendapatkan perhatian mengingat bahan dasar penyedap rasa ada yang terbuat dari yang diharamkan. Sebaiknya masyarakat harus mulai meninggalkan hal demikian karena dari efek kesehatan tingginya angka konsumsi bisa menimbulkan berbagai penyakit degeneratif.

Kedua, dari aspek perolehan secara otomatis seluruh bahan yang mereka peroleh diyakini hasil jerih payah mereka dalam mencari nafkah yang halal bukan hasil melakukan pekerjaan yang diharamkan.

Ketiga, proses secara umum, penulis menyimpulkan hampir mendekati $100 \%$ mengingat masih ada dalam prosesi tertentu yang secara syariat masih belum memenuhi tuntunan sebagai contoh adalah dengan adanya acara ngagantian getih berupa penyembelihan ayam yang darahnya ditotolkan pada kening bayi yang baru lahir dan ibu yang bersalin. Hal ini secara keterangan tidak dicontohkan 
atau diriwayatkan dalam hadits manapun dan diyakini ini adalah masih tradisi dari ajaran masa lalu sebelum Islam masuk ke kawasan ini.

Keempat, dari aspek higiene, tampaknya perlu diberikan porsi perhatian besar mengingat masyarakat belum sepenuhnya menjalankan standar penjaminan keamanan dan kesehatan pada makanan. Contohnya dalam penggunaan peralatan untuk memotong sayur dan daging masih digunakan alat yang sama; belum diterapkannya alat pelindung; masih adanya yang orang yang merokok di sekitar area memasak (para bapak yang membantu); lupa mencuci tangan saat aakan memasak; meletakkan bahan makanan di tempat yang tidak semestinya; pengolahan makanan yang overcook; penggunaan plastik daur ulang sebagai pembungkus ataupun styrofoam; piranti memasak ada yang terbuat dari bahan berbahaya seperti plastik, alumunium, styrofoam, dsb.

Kelima adalah dari sisi sanitasi, penulis memastikan bahwa aspek ini pun masih harus diperhatikan dengan sangat baik oleh seluruh warga masyarakat desa karena masih belum dikatakan $100 \%$ baik. Hal ini terbukti dari sisi penempatan dapur yang dekat sekali dengan WC; masih belum tertatanya dapur dengan baik; sirkulasi udara masih kurang; penggunaan air bersih yang masih minim sebagai medium memasak; tempat pembuangan sampah yang kurang diperhatikan.

\section{SIMPULAN}

Berdasarkan hasil analisis data, jumlah ragam kuliner yang ada di kawasan Desa Pakuwon, Kecamatan Cisurupan, Kabupaten Garut mencapai 189 jenis yang terbagi ke dalam delapan kategori utama yaitu: makanan pokok (9\%), sup (3\%), lauk-pauk (23,8\%), lalab (3\%), sambal (6,8\%), kerupuk/ keripik (9\%), kudapan $(60,3 \%)$, dan bubur $(2,6 \%)$.

1. Berdasarkan data bandingan sebelumnya yang berjumlah 40 teknik, penulis pada akhirnya menemukan bahwa di era sekarang terjadi adanya penambahan (69 teknik untuk khazanah kuliner Sunda), yang masih eksis sampai sekarang (26 teknik), dan tidak digunakan/ jarang dipakai (16 teknik), dan teknik yang berkembang khusus di desa ini mencapai (55 teknik). Dalam praktiknya masyarakat memanfaatkan teknik pengolahan kuliner dalam ragam masakan yang paling menonjol jumlahnya berentang dari urutan yang tertinggi adalah 1 teknik (32,3\%), 2 teknik $(24,3 \%), 4$ teknik (18,5\%), 3 teknik (15,3\%), 5 teknik (4,8\%), 5 teknik $(4,8 \%), X \geq 8$ teknik $(2,6 \%)$, dan 7 teknik $(0,5 \%)$.

2. Simpulan berikutnya adalah konteks pembuatan dan penyajian kuliner yang tumbuh dan berkembang di masyarakat Desa Pakuwon terbagi atas rutinitas kebutuhan domestik keluarga, komersial, dan acara seremonial yang berupa adat ataupun keagamaan terkait pernikahan, kehamilan, kelahiran, kematian, keselamatan dan musibah, peringatan hari-hari keagamaan maupun hari-hari besar nasional. Adapun jumlah sajian makanan dalam konteks sehari-hari tidak kurang dari 6 kategori utama yaitu makanan pokok, sambal, lalaban, lauk-pauk, kudapan, dan kerupuk. Namun demikian dalam upacara perhelatan seperti pernikahan ataupun 
sunatan 8 kategori utama makanan bisa disajikan semuanya jumlahnya bisa mncapai puluhan jenis makanan yang dihidangkan.

3. Simpulan berikutnya adalah kehalalan aspek material bahan makanan hampir mendekati $100 \%$ halal; aspek perolehan diyakini halal $100 \%$; proses secara umum hampir mendekati $100 \%$ mengingat masih ada dalam prosesi tertentu yang secara syariat masih belum memenuhi tuntunan; aspek higiene dan sanitasi masih kurang.

\section{DAFTAR PUSTAKA}

Ahmadi, Abu. (2003). Ilmu Sosial Dasar: Mata Kuliah Dasar Umum. Jakarta: Rineka Cipta.

Andriani, Dini dkk. (2015). Laporan Pendahuluan Kajian Pengembangan Wisata Syariah di Indonesia. Jakarta: Asisten Deputi Penelitian Dan Pengembangan Kebijakan Kepariwisataan Deputi Bidang Pengembangan Kelembagaan Kepariwisataan Kementerian Pariwisata [16 Juni 2017].

Arikunto, S. (2002). Prosedur Suatu Penelitian: Pendekatan Praktek. Edisi Revisi Kelima. Jakarta : Rineka Cipta.

Atja dan Danasamita, Saleh. (1981). Sanghyang Siksakandang Karesian: Naskah Sunda Kuno Tahun 1518 Masehi. Bandung: Proyek Pengembangaan Permuseuman Jawa Barat.

Darpan dkk. (2013). Kompendium Istilah Sistem Pertanian Tradisional Sunda. Bandung: Pustaka Jaya dan Universitas Padjadjaran.

Darwis, Riadi. (1995). Masyarakat Sunda dalam Sorotan Sosial, Budaya, Agama dan Kepercayaannya. Bandung: Naskah Penelitian yang belum diterbitkan.

Darwis, Riadi. (1995). Teknik Kuliner Tradisional Sunda Sebuah Sumbangan bagi Khazanah Kuliner Indonesia. Bandung: Naskah penelitian yang belum dipublikasikan.

Furchan, Ahmad. (2004). Pengantar Penelitian Dalam Pendidikan. Yogyakarta : Pustaka Belajar.

Ghony, Djunaidi \& Fauzan Almansyur. (2012). Metodologi Penelitian Kualitatif. Jogjakarta: Ar-Ruzz Media.

Kementerian Pariwisata dan Ekonomi Kreatif Republik Indonesia. (2014). Lampiran Peraturan Menteri Pariwisata dan Ekonomi Kreatif Republik Indonesia Nomor 2 Tahun 2014 tentang Pedoman Penyelenggaraan Usaha Hotel Syariah. (pdf). Tersedia: https://www.bing.com/search?q=Pedoman+ Penyelenggaraan+Usaha + Hotel+Syariah\&form $=$ PRIDID\&pc=EUPP \&htt psmsn=1\&refig=584c4613af1e4fd0b04ea3c25313dd4d\&pq=pedoman+pe nyelenggaraan+usaha+hotel + syariah $\& s c=0-11 \& s p=-1 \& q s=n \& s k=[$ Juni 2016].

Kusmayadi. (2004). Statistika Pariwisata Deskriptif. Jakarta : PT. Gramedia Pustaka Utama.

Margono. (2004). Metodologi Penelitian Pendidikan. Jakarta: Rineka Cipta. 
Menteri Kebudayaan dan Pariwisata RI. (2010). Pedoman Programa Nasional Pemberdayaan Masyarakat Mandiri Pariwisata melalui Desa Wisata. Jakarta; Kementerian Kebudayaan dan Pariwisata RI.

Menteri Kebudayaan dan Pariwisata RI. (2010). Peraturan Menteri Kebudayaan dan Pariwisata Nomor: PM.26/UM.001/ MKP/2010 tentang Pedoman Umum Program Nasional Pemberdayaan Masyarakat (PNPM) Mandiri Pariwisata melalui Desa Wisata. Jakarta: Kementerian Kebudayaan dan Pariwisata RI.

Noorduyn, J. Dan Teeuw, A. (2009). Tiga Pesona Sunda Kuna. Jakarta: Pustaka Jaya dan KITLV Jakarta.

Pemerintah Desa Pakuwon, Kecamatan Cisurupan, Kabupaten Garut. 2016. Profil Desa Pakuwon. Garut: Dokumen Prodil Desa Pakuwon.

Purwanto, Erwan Agus dan Dyah Ratih Sulistyastuti. (2011). Metode Penelitian Kuantitatif untuk Administrasi Publik dan Masalah-Masalah Sosial. Yogyakarta: Gava Media.

Quran Terjemah. (2013). (online). Tersedia: http://quranterjemah.com/?mod=quran.pencarian.show\&cari=1 $\quad[17$ November 2016].

Rofi'i, Sunhadji, Haji. (2010). Pengertian Halal dan Haram Menurut Ajaran Islam. (online). Tersedia: http://www.halalmuibali.or.id/?p=56 $[17$ November 2016]

Rosidi, Ajip dkk. (2000). Ensiklopedia Sunda: Alam, Manusia, dan Budaya Termasuk Buday Cirebon dan Betawi.Jakarta: PT Dunia Pustaka Jaya, The Toyota Foundation Tokyo, dan Yayasan Kebudayaan Rancage.

Satori, Djam'an dan Komariah, Aan. (2014). Metodologi Penelitian Kualitatif, Bandung : Alfabeta.

Stevenson, Daniel R. (1991). Cookery the Process Approach. England: Stanley Thornes.

Sudaryat, Yayat. (2015). Wawasan Kesundaan. Bandung: Jurusan Pendidikan Bahasa Daerah, Fakultas Pendidikan Bahsa dan Sastra, Universitas Pendidikan Indonesia.

Sugiyono. (2008). Metode Penelitian Kuantitatif Kualitatif dan R\&D. Bandung: Alfabeta.

Sumarsono. (2004). Metodologi Penelitian Akuntansi Beserta Contoh Interpretasi Hasil Pengolahan Data. Edisi Revisi. Surabaya.

Suryani NS, Elis. (2011). Ragam Pesona Budaya Sunda. Bogor: Ghalia Indonesia. 